\title{
Review
}

\section{Recognition or disagreement: A critical encounter on the politics of freedom, equality, and identity}

\author{
Axel Honneth and Jacques Rancière \\ Katia Genel and Jean-Philippe Deranty (eds.) \\ Columbia University Press, New York and Chichester, West Sussex, 2016, \\ $\mathrm{x}+229 \mathrm{pp}$., ISBN: 978-0231177160
}

Contemporary Political Theory (2017) 16, 394-397. doi:10.1057/s41296-016-0082-y; advance online publication 6 December 2016

The present volume dates back to a June 2009 encounter between Jacques Rancière and Axel Honneth in the "mythical building" (p. 107) of the Frankfurt Institute for Social Research with the discussion having been moderated by Christoph Menke. Recognition or disagreement embraces the lectures and two further texts by Rancière and Honneth as well as the essays authored by editors Katia Genel and Jean-Philippe Deranty.

It comes as no surprise that the volume opens with the following remarks: Axel Honneth is presented as "the famous German theorist of recognition who took over the legacy of the Frankfurt School and especially of Jürgen Habermas," and Jacques Rancière as "the eminent French thinker of the disagreement (mésentente) who broke with the Althusserian tradition" (p. 3, Genel). Being renowned representatives of their respective theoretical backgrounds, Rancière and Honneth meet one another as contenders. However, as critics of these very same backgrounds, they negotiate the numerous points of overlap where their theoretical positions closely merge.

Before coming to the common traits in Honneth's and Rancière's theoretical edifices, let me shortly elaborate on the terms of their disagreement. Whereas Honneth, who is heir to hermeneutics and partly to Habermas' social philosophy as well, employs a sociological view on political and social phenomena, Rancière's intellectual endeavor refutes any kind of "sociology" (or, even more, "social" or "political philosophy"). Instead of explaining or theoretically supporting the existing (or possible) political structures, regimes, and institutions, he is interested in the multiple ways of changing these structures, norms, and what he calls the "distribution of the sensible" (p. 136). One may even finesse this opposition and claim that while Honneth is interested in archaic politics as politics of instituting,

(c) 2016 Macmillan Publishers Ltd. 1470-8914 Contemporary Political Theory Vol. 16, 3, 394-397 www.palgrave.com/journals 
constituting, and upholding the societal structures (and toward his later work this is even more the case), Rancière is interested in an-archic (not anarchist) challenges for these structures, which lay bare social injustices and political lies. Therefore, due to their adherence to decisively different theoretical foils, the terms as well as the theoretical 'catchwords' that Honneth and Rancière employ possess a polyvalence that obliges the reader to considerately inspect the meanings these respective terms and words are beset with. These terms can be enumerated in pairs, such as recognition versus disagreement, freedom versus equality, recognitive order versus police order, ethical life (Sittlichkeit) versus democracy, and identification versus subjectivization.

As regards the two central terms of their "mésentente" - disagreement and recognition -, Jean-Phillipe Deranty (2003) has previously attempted to read Rancière's understanding of political subjectivization in proximity to Honneth's idea of recognition (which is closely related to the idea of "ethical life" or Sittlichkeit). In this volume, Honneth attempts a similar approximation of Rancière's and his own emancipatory thinking. However, Rancière is rather skeptical of any subsumption of his own theoretical position under the vocabulary of recognition theory. As recognition theory comprises dimensions of idealistic and individualistic philosophy, and of a "juridical definition of the person" (p. 87), Rancière considers these Hegelian remnants too high a cost to pay for a general theory of the subject. This also becomes obvious in his reaction to the "desire for egalitarianism" (p. 99), which Honneth believes he finds in Rancière's disagreement (p. 102). Rancière refutes any trace of "desire" in his interpretation of political processes (p. 111). (Here, Deranty observes Rancière's reluctant "antipsychologism," p. 49.) Nevertheless, no matter how justified Rancière's skepticism toward possible intersections of political theory and (individual) psychology may be, by thoroughly rejecting the notion of "desire" he seems to miss the opportunity to explain how or why the events of disagreement or, speaking of esthetics, the new distributions of the sensible emerge in the first place.

At one point, the mésentente of Rancière and Honneth becomes entertaining, and the reader can sense the vivid atmosphere of the live discussion. After Honneth implies that Rancière tends to describe the "enactment of the political[,] as being a state of exception," Rancière interrupts him by saying: "No. I don't think of it as a state of exception." Probably taken by surprise, Honneth replies: "No? I thought so" (p. 129). This quid pro quo is a sort of red thread in the volume, which makes it interesting and exciting to read.

In his sketch of Rancière's central elaboration of the inherently opposed logics of politics and police, Honneth makes another small faux pas. He maintains that in Rancière, there exists "a certain tension between the reference to equality and the specific normative principle on which [all political orders] base the legitimation or justification of their own form of government" (p. 115). For those familiar with Honneth's work (especially with his late The Right of Freedom), his subsequent 
remark that he does not see "that there is this tension" (p. 116) comes as no surprise. Honneth's and Rancière's diverging perspectives on the political come to the fore precisely in the latter's insistence on the "wrong" as the fundamental truth underlying all (democratic or other) political orders, and in Honneth's sometimes benevolent blindness toward the shortcomings and impasses of these normative political orders. Instead of criticizing the democratic order for its mere "promise" of democracy that is in fact a "lie" that incorporates an elementary "wrong," he conceptualizes democracy as an institutional and political attempt at "inclusion" by way of the unavoidable "social basis of exclusion" (p. 116): "All kinds of political orders must refer to the idea of inclusion, so that there is an internal problem for them to justify forms of exclusion ...." (p. 116) Therefore, Honneth takes the perspective of the "ruler," of those who are "in charge" or who are "the police." To sum up, what Rancière criticizes as "police order" is in Honneth's terminology "recognitive order" (p. 103): Although still being an order of rule, the recognitive order does empower groups and individuals to actions that result in inclusion instead of keeping them permanently excluded.

Honneth points to yet another distinction between Rancière and himself that proves to be pertinent: between an "internal" and an "external struggle for recognition" (pp. 105-106). While Honneth ascribes to Rancière a theoretical interest primarily in the "interruption of the whole normative order," he himself claims to be interested in the internal struggle for recognition, which "does not call into question the existing principles of recognition ... but calls into question the existing modes of their interpretation" (p. 105). While agreeing with Honneth, I believe that it is precisely this point wherein the crucial paradox of Rancière's politics lies: reflecting upon acts of interruption by groups who call the normative order into question, Rancière nevertheless refuses to raise claims on institutionalizing the "revolutionary" politics of disagreement or on founding a new or another order. By doing so, he even seems to commit to the internal struggle for recognition: "This means that political action is not simply the negative interruption of the police domination ... It inscribes effects of equality in our laws and our practices. And those inscriptions, in turn, allow new political conflicts and actions" (p. 125).

By departing from an aside by María Pía Lara, who shares closely with Reinhart Koselleck and Hannah Arendt the idea that political concepts are not just matters of political theory but that they possess an "internal temporal structure" (Lara 2013: 46) and are thus related to "future actions in politics" (Lara 2013: 47), one reaches another crucial term of disagreement between Rancière and Honneth: the question of the political telos. Although admitting that the idea of telos is courageous and even militant, Rancière is critical about the conviction that "some kind of faith in progress" (p. 92), some "orientation toward the future" (p. 94), is necessary. Instead he remarks that equality cannot be a promise but only "the power that is already at work in all our relations" (p. 95). Here, it is Rancière who seems to 
misinterpret the companion's (and some other's) conceptualizations of telos: notwithstanding its historical misuses, the term is not to be simplified as an instrument of false promises. Without telos as a "motor of history" (p. 95), how could the people, once they realize that they are always already equal, politically enact this knowledge?

From this, it follows that Rancière's and Honneth's perspectives on politics and political orders are themselves of two kinds of "order," but that they are not incompatible: Rancière's critique of the "police order" begins precisely at the moment in which the Honnethian "recognitive order" shows its restrictiveness and even cynicism. If one may endeavor a tertium datur between these two theoreticians, it would consist in the revolutionary critique of the "police logic" combined with the necessary work on those institutions of our recognitive order that diminish the influence of "police" for the sake of "politics." Finally, the conjunction "or" in the volume title may be taken as a signal not only of an "either-or" but also of an "as well as." This "in-principle agreement" (p. 37, Deranty) is not to be found between the lines but is explicitly addressed by the disputants, who both share a "commitment to the idea of a struggle against injustice" (p. 40, Deranty). Therefore, this volume contains not only terms of disagreement but many points of comparison and intersection (cf. p. 68, Deranty) and invites the reader to theoretically negotiate between an an-archic and " "poststructuralist' suspicion toward normativity" (p. 65) on the one side and the optimistic (or perhaps apocalyptic?) belief in institutions that enable equality, freedom, and recognition on the other.

\section{References}

Deranty, J.P. (2003) Jacques Rancière's contribution to the ethics of recognition. Political Theory 31(1): $136-156$.

Lara, M.P. (2013) The Disclosure of Politics. Struggles Over the Semantics of Secularization. West Sussex: Columbia University Press.

Ivana Perica

ÖAW Scholarship (JESH), Achengasse 1/15, 1210 Vienna, Austria ivana.perica@univie.ac.at 